\title{
COCHLEAR IMPLANTATION IN CONGENITALLY DEAF CHILDREN WITH ISOLATED LARGE VESTIBULAR AQUEDUCT: A SURGEON'S PERSPECTIVE
}

\author{
Rabindra B. Pradhananga, John K. Thomas, Kiran Natarajan, \\ Raghunandhan Sampathkumar, Mohan Kameswaran \\ Department of Implantation Otology, Madras ENT Research Foundation, Chennai, India
}

Corresponding author: Rabindra B. Pradhananga, e-mail: rabindrabp@yahoo.com

\begin{abstract}
Background: The vestibular aqueduct is a bony canal containing the endolymphatic duct. Its average diameter is 0.6 to $1.5 \mathrm{~mm}$ at its midpoint between the crus communes and its opening at the posterior cranial fossa. If the radiographic diameter at this point is more than $1.5 \mathrm{~mm}$, it is considered a case of large vestibular aqueduct (LVA). It is the most common radiographically detectable inner ear anomaly in congenital hearing loss. LVA with hearing loss is described as LVA syndrome (LVAS). In children with LVA, cochlear implantation has been proven to be effective in increasing both auditory perception and speech and language development.
\end{abstract}

Material and methods: The study was carried out from March 2009 to March 2014 on 9 isolated LVAS cases among 406 congenitally deaf children who had been implanted at the Madras ENT Research Foundation (MERF), Chennai, India. This observational study is focused on pre-operative assessment, surgical issues, and postoperative follow-up.

Results: Five males and four females less than six years old were detected with LVAS. There was a pulsatile stapes in five cases and a CSF gusher in eight cases. CSF gushers were well controlled during surgery by tightly sealing the insertion site with soft tissue. An intraoperative mannitol drip was used in six patients and fibrin glue in three. Postoperative oral acetazolamide was used routinely in cases of CSF gusher. No early postoperative complications were seen. Intraoperative impedance and neural telemetry were all satisfactory.

Conclusions: Cochlear implantation in LVAS is feasible and effective. However, CSF gushers are common and require appropriate management and follow-up.

Keywords: cerebrospinal fluid pressure • cochlear implantation • vestibular aqueduct

\section{IMPLANTES COCLEARES EN NIÑOS CON SORDERA CONGÉNITA Y CON}

EL DEFECTO SEPARADO DEL ACUEDUCTO VESTIBULAR AGRANDADO-ESTUDIO DESDE EL PUNTO DE VISTA DE UN CIRUJANO

\section{Resumen}

Introducción: El acueducto vestibular es un conducto óseo que incluye el ducto endolinfático. La longitud media de su diámetro en el punto central entre las ramas óseas comunes y la unión posterior con la parte inferior del cráneo es de 0,6 a 1,5 mm. En el caso de que la radiografía demuestre que el diámetro en este punto sea superior a 1,5 mm, entonces este caso se definirá como el acueducto vestibular agrandado (AVA; LVA en inglés). Es el trastorno de la estructura del oído interno, dentro del contexto de la sordera congénita, detectado con la mayor frecuencia a través de una prueba de radiografía. El caso de LVA, acompañado de la pérdida auditiva, se denomina como el síndrome AVA (LVA síndrome, LVAS en inglés). El implante coclear en los niños con AVA resultó ser eficaz en el aspecto de mejora tanto de la percepción auditiva, como y del habla y del desarrollo lingüístico.

Materiales y métodos: El estudio se realizó en el periodo comprendido entre el marzo del 2009 y el marzo del 2014 en base a 9 casos seleccionados del SAVA (LVAS en inglés), detectados entre los 406 niños con sordera congénita. Los pacientes fueron sometidos a la implantación del implante auditivo en el centro indio Madras ENT Research Foundation (MERF) en Chennai. El estudio se centró en la evaluación de pre- y postoperatorio y en los problemas de cirugía.

Resultados: El SAVA fue descubierto en 5 pacientes niños y en 4 pacientes niñas menores de 6 años. En cinco casos se observó el fenómeno de la palpitación del estribo y en 8 - el incremento de la presión del líquido cefalorraquídeo. Dicha presión fue adecuadamente controlada durante la intervención de cirugía mediante una protección estanca de la incisión del tejido blando. A seis pacientes se les suministró el manitol por la vía intravenosa y en tres pacientes se aplicó la cola de fibrina. De forma 
Pradhananga et al. - Cochlear implantation in congenitally deaf children with isolated large vestibular aqueduct...

rutinaria, tras la operación, a los pacientes con la presión del líquido cefalorraquídeo incrementada se les administró acetazolamide vía bucal. No se ha observado ninguna complicación postoperatoria temprana. Los resultados de las pruebas intraoperatorias (de la impedancia y telemetría) han sido satisfactorios.

Conclusiones: La implantación con el implante coclear en los casos del SAVA está justificada y resulta eficaz, sin embargo, es frecuente que vaya acompañada de un incremento de la presión del líquido cefalorraquídeo, para lo que es necesario el uso de los respectivos procedimientos y seguimiento.

Palabras clave: presión del líquido cefalorraquídeo • implante coclear • acueducto vestibular

\title{
УЛИТКОВАЯ ИМПЛАНТАЦИЯ У ДЕТЕЙ С ВРОЖДЕННОЙ ГЛУХОТОЙ С ПРЕПАРИРОВАННЫМ БОЛЬШИМ ВОДОПРОВОДОМ ПРЕДДВЕРИЯ - ИССЛЕДОВАНИЯ С ТОЧКИ ЗРЕНИЯ ХИРУРГА
}

\section{Изложение}

Введение: Водопровод преддверия - это костный канал, который содержит канал эндолимфы. Средняя длина его диаметра в центральном пункте между общими ответвлениями и задним соединением внизу черепа составляет 0,6 до 1,5 мм. Если радиография покажет, что диаметр в этой точке составляет более 1,5 мм, такой случай называется большим водопроводом преддверия (LVA). Это является самым частым нарушением структуры внутреннего уха в контексте врожденной глухоты, которое обнаружиается вследствие радиографического исследования. Случай LVA, который сопровождается потерей слуха, называется синдромом LVA (LVA syndrome, LVAS). Улитковая имплантация у детей с LVA оказалась эффективной в области улучшения как слухового восприятия и речи, так и речевого развития.

Материал и методы: Исследование выполнено в период с марта 2009г. по март 2014г. на основании девяти выбранных случаев LVAS, обнаруженных среди 406 детей с врожденной глухотой. Пациенты были подвергнуты операции имплантации в индийском центре Madras ENT Research Foundation (Мадрас ЭНТ Рисерч Фаундейшн) (MERF) в Ченнаи. Исследование концентрировалось на предоперационной оценке, хирургических проблемах и послеоперационном обследовании пациентов.

Результаты: LVAS обнаружено у пяти пациентов и четырех пациенток младше шести лет. В пяти случаях появилось явление пульсирующего стремечка,а в восьми - повышение давления спинномозговой жидкости. Это давление было соответствующим образом контролируемое во время операции путем плотной защиты надреза мышечной ткани. Шесть пациентов получили капельницы с маннитом, а у троих был применен фибриновый клей. Стандартно, после операции пациенты с повышенным давлением спинномозговой жидкости приняли внутрь ацетазоламид. Никаких послеоперационных осложнений не обнаружено. Результаты интраоперационных измерений (импеданции и телеметрии) - удовлетворительные.

Выводы: Улитковая имплантация в случаях LVAS является обоснованной и эффективной, однако при этом часто может появляться повышенное давление спинномозговой жидкости, которое требует применения соответствующих процедур и обследования.

Ключевые слова: давление спинномозговой жидкости • улитковая имплантация • водопровод преддверия

\section{IMPLANTACJA ŚLIMAKOWA U DZIECI Z WRODZONĄ GLUCHOTĄ Z ODPREPAROWNYM DUŻYM WODOCIĄGIEM PRZEDSIONKOWYM - BADANIE Z PUNKTU WIDZENIA CHIRURGA}

\begin{abstract}
Streszczenie
Wprowadzenie: Wodociąg przedsionkowy jest kanałem kostnym zawierającym przewód śródchłonki. Średnia długość jego średnicy w punkcie środkowym pomiędzy odnogami wspólnymi i łączeniem tylnym dołem czaszki wynosi 0,6 do 1,5 mm. Jeżeli radiografia wykaże, że średnica w tym punkcie wynosi więcej niż $1,5 \mathrm{~mm}$, przypadek taki określa się jako duży wodociąg przedsionkowy (LVA). Jest to najczęściej wykrywane w wyniku badania radiograficznego zaburzenie struktury ucha wewnętrznego w kontekście wrodzonej głuchoty. Przypadek LVA, któremu towarzyszy utrata słuchu, określany jest jako zespół LVA (LVA syndrome, LVAS). Implantacja ślimakowa u dzieci z LVA okazała się skuteczna w obszarze polepszenia zarówno percepcji słuchowej, mowy, jak i rozwoju językowego.
\end{abstract}


Materiał i metody: Badanie przeprowadzono w terminie od marca 2009 r. do marca 2014 r. na postawie dziewięciu wybranych przypadków LVAS wykrytych spośród 406 dzieci z wrodzoną głuchotą. Pacjenci zostali poddani zabiegowi implantacji w indyjskim ośrodku Madras ENT Research Foundation (MERF) w Chennai. Badanie koncentrujące się na ocenie przedoperacyjnej, problemach chirurgicznych i pooperacyjnej obserwacji pacjentów.

Wyniki: LVAS wykryto u pięciu pacjentów i czterech pacjentek poniżej szóstego roku życia. W pięciu przypadkach wystąpiło zjawisko pulsującego strzemiączka, a w ośmiu - wzrost ciśnienia płynu mózgowo-rdzeniowego. Ciśnienie to było odpowiednio kontrolowane podczas zabiegu poprzez szczelne zabezpieczenie nacięcia tkanki miękkiej. Sześciu pacjentom podano kroplówkę z mannitolem, a u trzech zastosowano klej fibrynowy. Rutynowo, po operacji, pacjentom z podwyższonym ciśnieniem płynu mózgowo-rdzeniowym podano doustnie acetazolamide. Nie zaobserwowano żadnych wczesnych powikłań pooperacyjnych. Wyniki pomiarów śródoperacyjnych (impedancji i telemetrii) były zadowalające.

Wnioski: Implantacja ślimakowa w przepadkach LVAS jest uzasadniona i skuteczna, jednakże często może tutaj współwystępować podwyższone ciśnienie płynu mózgowo-rdzeniowe, które wymaga zastosowania odpowiednich procedur i obserwacji.

Słowa kluczowe: ciśnienie płynu mózgowo-rdzeniowego • implantacja ślimakowa • wodociąg przedsionkowy

\section{Background}

The vestibular aqueduct (VA) is a tiny, bony canal in the otic capsule that communicates the postero-medial portion of the vestibule with the posterior cranial fossa. The endolymphatic duct runs inside the VA connecting the endolymphatic sac and the vestibule $[1,2]$. During fetal development, the vestibular aqueduct starts out as a wide tube; by the fifth week it narrows and by midterm it approaches adult dimensions and shape. When the diameter of the VA is wider than normal (over $1.5 \mathrm{~mm}$ ), it is termed Large Vestibular Aqueduct (LVA). When this anatomical anomaly is associated with symptoms such as hearing loss or balance disturbance, it is referred to as LVA syndrome (LVAS). Valvassori and Clemis were the first to describe and coin the term after finding an association between LVA and SNHL in 50 cases [1].

On a CT scan, the LVA is defined radiologically as an anteroposterior VA diameter greater than $1.5 \mathrm{~mm}$ measured midway between its aperture and the crus communes $[1,3]$. LVAS is commonly associated with non-syndromic deafness, although it can also be associated with syndromic hearing loss as in Pendred syndrome [4], branchio-otorenal syndrome [5], and CHARGE association [6]. In addition, it can be associated with other anatomical defects such as cochlear aplasia, hypoplasia, and Mondini deformity. As to the genetics of LVAS, it has been postulated to be inherited as an autosomal recessive trait [7].

Cochlear implantation has been proven to be effective in increasing both auditory perception and speech and language development in children with LVAS [8]. Most of the literature reports CSF gushers or leaks as a common problem encountered during and after cochlear implantation [8].

Cochlear implantations were performed in 406 congenital deaf children (below 6 years) in the 5 years from March 2009 to March 2014 at the Madras ENT Research Foundation (MERF), Chennai, India. Among these children, 35 were detected with LVA, of which nine had isolated LVA and 26 had associated Mondini deformity. The aim of this study was to observe any significant history, preoperative assessment, surgical issues, and postoperative follow-up in the nine isolated LVAS cases.

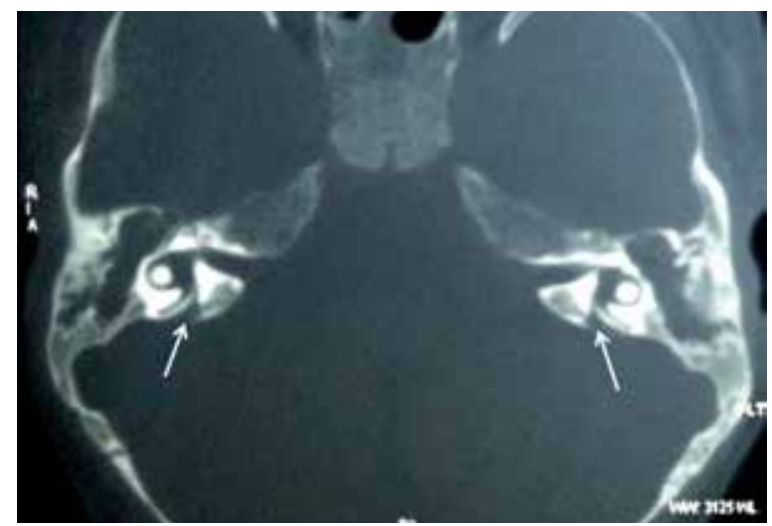

Figure 1. Bilateral large vestibular aqueducts (arrows)

\section{Material and methods}

After clearance from the ethical review board of the institute, the study was carried out on the nine isolated LVAS cases. Preoperative assessment was performed, as in other cochlear implant candidates, according to the guidelines of the Cochlear Implant Group of India (CIGI). A full history, including parents' consanguinity, and antenatal, natal, and postnatal problems, was taken. A detailed general examination with ENT and systemic examination of all the children was performed. They were also assessed by an audiologist, psychologist, and speech therapist. The detailed audiological work-up, including behavioral audiometry, tympanometry, DPOAEs, and brainstem auditory evoked response audiometry (BERA), was performed in all cases. LVAS was diagnosed on the basis of HRCT temporal bone.

All nine children were vaccinated with Quadri Meningo (Meningococcal Polysaccharide: Group A, C, Y \& W135) and Sii Hib Pro (Haemophilus Type B conjugate) vaccine at least 4 weeks prior to surgery.

The patients and their parents were introduced to other implantees before the surgery at the habilitation centre run by MERF and educated with regard to maintenance of the implant and auditory verbal habilitation.

Surgical issues and findings, and various problems including CSF gusher, difficult insertion, and techniques for 
Pradhananga et al. - Cochlear implantation in congenitally deaf children with isolated large vestibular aqueduct...

Table 1. Pre-operative assessment

\begin{tabular}{|c|c|c|c|c|c|c|c|c|}
\hline S.N. & Pt ID & $\begin{array}{l}\text { Age } \\
(\mathrm{Y} / \mathrm{M})\end{array}$ & Gender & $\begin{array}{c}\text { Perinatal/ } \\
\text { maternal } \\
\text { significant history }\end{array}$ & Consanguinity & $\begin{array}{l}\text { Prior use of } \\
\text { hearing aid }\end{array}$ & Milestone & $\begin{array}{c}\text { CT scan measurement } \\
\text { of VA }\end{array}$ \\
\hline 1 & AA & $2 / 9$ & Male & - & + & 2 years & $\mathrm{N}$ & $1.95 \mathrm{~mm}$ \\
\hline 2 & KD & 2 & Female & - & + & 4 months & $\mathrm{N}$ & $1.55 \mathrm{~mm}$ \\
\hline 3 & EK & $3 / 2$ & Female & - & - & - & $\mathrm{N}$ & $1.8 \mathrm{~mm}$ \\
\hline 4 & SR & $2 / 11$ & Male & - & + & - & $\mathrm{N}$ & $1.7 \mathrm{~mm}$ \\
\hline 5 & BS & $2 / 1$ & Male & Both parents deaf & - & - & $\mathrm{N}$ & $1.6 \mathrm{~mm}$ \\
\hline 6 & YP & $2 / 1$ & Female & - & - & - & $\mathrm{N}$ & $1.65 \mathrm{~mm}$ \\
\hline 7 & $\mathrm{KY}$ & $4 / 8$ & Female & - & - & 2 years & $\mathrm{N}$ & $1.9 \mathrm{~mm}$ \\
\hline 8 & SV & 2 & Male & - & + & - & $\mathrm{N}$ & $1.6 \mathrm{~mm}$ \\
\hline 9 & MG & $5 / 9$ & Male & - & - & - & $\mathrm{N}$ & $1.8 \mathrm{~mm}$ \\
\hline
\end{tabular}

- absent; + present.

Table 2. Intraoperative findings and management

\begin{tabular}{|c|c|c|c|c|c|c|c|c|}
\hline S.N. & Pt. ID & Implant & $\begin{array}{l}\text { Pulsatile stapes } \\
\text { sign }\end{array}$ & CSF gusher & $\begin{array}{l}\text { Use of } \\
\text { mannitol }\end{array}$ & Insertion site & $\begin{array}{l}\text { Use of fibrin } \\
\text { glue }\end{array}$ & Use of acetazolamide \\
\hline 1 & $\mathrm{AA}$ & $\mathrm{Cl} 1400$ & + & + & + & C & + & + \\
\hline 2 & KD & $\mathrm{Cl} 1400$ & - & + & - & C & - & + \\
\hline 3 & EK & $\begin{array}{l}\text { MED-EL } \\
\text { Combi40+ }\end{array}$ & + & + & + & C & + & + \\
\hline 4 & SR & MED-EL Sonata & + & + & + & C & - & + \\
\hline 5 & BS & MED-EL Pulsar & - & + & + & C & - & + \\
\hline 6 & YP & MED-EL Sonata & - & - & - & RW & - & - \\
\hline 7 & KY & MED-EL Sonata & + & + & - & RW & - & + \\
\hline 8 & SV & MED-EL Sonata & - & + & + & RW & + & + \\
\hline 9 & MG & MED-EL Sonata & + & + & + & C & - & + \\
\hline
\end{tabular}

C - cochleostomy; RW - round window.

control of CSF gusher were recorded. Intraoperative impedance and neural telemetry were performed.

Postoperatively, the patients were reviewed regarding complications, especially vestibular dysfunction and CSF otorhinorrhoea, switch-on, and progress in speech and language development.

\section{Results}

Five male and four female children were detected with LVAS among the 406 deaf children of age less than 6 years who had cochlear implantation over the 5 years of study (an incidence of $2.21 \%$ ). Four children were born from consanguinous parents. In all cases there was no history of maternal illness including TORCH, Rh incompatibility, neonatal jaundice, meningitis, visual disturbance, hypothyroidism, or syncopal spells. There was no significant antenatal, natal, or postnatal history except in one case whose parents were both deaf. Their other developmental milestones were within normal limits. Their general examination showed normal IQ with no neurological dysfunction (Table 1). ENT examination showed normal external ear with normal and healthy looking tympanic membrane in all cases. There was no response to tuning fork tests in either ear. Other ENT examinations were within normal limits.

Behavioral audiometry of all cases showed profound sensorineural hearing loss and a type 'A' tympanogram in both ears. No DPOAEs were detected, confirming cochlear deafness. BERA showed absent wave III and V on both sides in all cases.

The round window niche was exposed via a posterior tympanotomy. In all three cases where the round window membrane was well exposed, a pulsatile round window membrane could be seen. In the other cases, where the round window membrane was not exposed, a cochleostomy was performed. The incudo-stapedial (I-S) joint 
was disarticulated in all cases to observe a possible pulsatile stapes sign. However only in five cases was a pulsatile stapes sign obvious. Out of 9 cases, a pulsatile cerebrospinal fluid (CSF) gusher was noted in 8 cases, either after making an incision on the round window membrane or on cochleostomy (Table 2). The severity of the gusher varied from mild to severe.

CSF gushers were managed successfully intraoperatively by reducing CSF pressure with a $20 \%$ mannitol intravenous drip ( $1.5 \mathrm{~g} / \mathrm{kg}$ body weight over 20 minutes). Complete insertion of the electrode array up to the marker ring was achieved in all cases except one, in which the last two electrodes of the MED-EL Sonata implant were not inserted. A soft harvested tissue (temporalis muscle) was used to seal the insertion site tightly around the electrode array. Fibrin glue was also used to achieve a water tight seal intraoperatively. However, in three cases, after elevating the head end of the operating table, the gusher decreased significantly and was well controlled without mannitol. The electrode array was then inserted. Further leakage after sealing the insertion site with soft tissue was not observed in any case.

The intraoperative impedance and neural telemetry were satisfactory in all cases. Prophylactic antibiotic coverage was used for 72 hours. Oral acetazolamide was given twice daily for three days for all the cases. During follow-up no patient had any vestibular symptoms or signs of CSF otorhinorhoea. There were no problems at or after switchon. No early postoperative complication developed.

\section{Discussion}

Large vestibular aqueduct syndrome is an important cause of congenital hearing loss. Valvassori and Clemis first described LVAS in 1978 with radiographic findings in congenitally malformed inner ears. Emmett [9] has reported up to a $12 \%$ incidence; however, we found only $2.2 \%$ LVA incidence among congenitally deaf children, which is almost the same as that found by Fahy et al. [10].

LVA is considered the most common radiographically detectable inner ear anomaly [1]. It may occur as an isolated anomaly, as in our 9 cases, or in association with other inner ear malformations like Mondini dysplasia (our other 26 cases). Valvassori and Clemis found the size of the aqueduct ranged from 1.5 to $8 \mathrm{~mm}$ in its anteroposterior diameter; however, we found that the size of the aqueduct in all our cases did not exceed $2 \mathrm{~mm}$ in diameter.

Jackler et al. [11] noticed that the hearing thresholds of individuals with LVA ranged from normal hearing (4\%) to profound deafness (39\%). Govaerts et al. [12] found that $90 \%$ of LVA cases had mixed hearing loss and a steady decrease of hearing at an average rate of $4 \mathrm{~dB}$ per year, a rate which can accelerate with exercise, minor head trauma, or upper respiratory infection. Children with LVAS can have unstable hearing, showing either fluctuating or progressive hearing loss. Ko et al. [13] have advised cochlear implantation before profound hearing loss develops. Since all our LVA cases had pre-lingual profound hearing loss prior to CI, the variability of their hearing status was outside the scope of the study.
During surgery, all the cochlear implantation steps were similar to normal. Out of nine cases, in three cases round window pulsation was clearly visible after exposing the round window membrane. A pulsatile stapes sign, described earlier by the authors [14], was discernible in five cases. Immediately after making an incision in the round window or during cochleostomy, a pulsatile CSF gusher was noticed in all cases except one. Although a CSF gusher is a well-known surgical risk in patients with LVA [8], no gusher was experienced by Harker et al. [15] in cochlear implantation in 5 LVAS patients, and Fahy [10] noticed it only in 2 of 4 cases. However, the overall incidence of a CSF gusher is generally low during normal cochlear implant surgery; Wootten et al. [16] encountered this condition in only $1 \%$ of patients undergoing cochlear implantation, with equal incidence in children and adults, and preoperative imaging was predictive in only $50 \%$ of cases.

To reduce a CSF gusher, we used a mannitol drip in six cases immediately after incising the round window membrane and/or cochleostomy. After insertion of the electrode array, it was easily controlled in all three cases by using a soft-tissue graft around the electrode array at the site of insertion. Various techniques to control CSF leaks have been described and differ according to the severity of the leak. In the case of LVA, it can be controlled without any extra technique except tightly packing the cochleostomy or insertion site. Very rarely, intra-operative management may require a lumbar drain. For inner ear malformation, gushers at surgery are directly related to intra-cerebral pressure (ICP). The mainstay of hyperosmolar treatment is to reduce the ICP at the time of the surgery. Loundon et al. [17] suggested osmotherapy as an effective means for controlling leakage during cochleostomy in LVA, and it could be effective in more severe malformations.

Acetazolamide has become a standard treatment for cerebrospinal fluid (CSF) leaks associated with intracranial hypertension. Although its role is not established in CI, we routinely use it in all CSF gushers as it reduces intracranial pressure. Fibrin glue was used only for a severe gusher. In three cases it was used to give a water-tight seal at the insertion site.

On the day of operation three patients had an episode of vomiting; however, all were discharged on the third postoperative day. No problems were noticed at subsequent follow-up. Switch-on was done three weeks postoperatively.

The progress in speech and language development in deaf children with LVAS after implantation was similar to those with normal inner ears, although its analysis was beyond the aim of this study. Various studies have already shown the success of cochlear implantation in LVAS [18-20]. Miyamoto [18] published results of a retrospective case-control study of outcomes of cochlear implantation in 23 patients with LVAS and of 46 control patients and concluded that cochlear implantation was as beneficial for the treatment of hearing loss in LVA as with the control patients. Vassoler et al. [19] evaluated retrospectively the hearing skills of 3 children with LVAS after cochlear implantation and saw a similar result. Chen et al. [20] performed a comparison study of 62 infants with LVAS in terms of development of auditory skills after cochlear implantation and found it was similar to infants with a normal inner ear. 


\section{Conclusions}

The results of the present cases and the review of the literature suggest that cochlear implantation in cases of isolated LVA is feasible and effective without intra- and postoperative complications.

\section{Acknowledgements}

The authors acknowledge the radiology department of the MNRI Centre, Chennai, for help in CT reports of the temporal bone. We also express our gratitude to the participants of the study.

\section{References:}

1. Valvassori GE, Clemis JD. The large vestibular aqueduct syndrome. Laryngoscope, 1978; 88: 723-8.

2. Becker TS, Vignaud J, Sultan A, Lachman M. The vestibular aqueduct in congenital deafness: evaluation by the axial projection. Radiology, 1983; 149: 741-4.

3. Dahlen RT, Harnsberger HR, Gray SD et al. Overlapping thin section fast spin echo MR of the large vestibular aqueduct syndrome: comparison with CT. Am J Neuroradiol, 1997; 18: 67-75.

4. Fugazzola L, Mannavola D, Cerutti $\mathrm{N}$ et al. Molecular analysis of the Pendred's syndrome gene and magnetic resonance imaging studies of the inner ear are essential for the diagnosis of true Pendred's syndrome. J Clin Endocrinol Metab, 2000; 85: 2469-75.

5. Stinckens C, Standaert L, Casselman JW et al. The presence of a widened vestibular aqueduct and progressive sensorineural hearing loss in the branchio-oto-renal syndrome. A family study. Int J Pediatr Otorhinolaryngol, 2001; 59: 163-72.

6. Murofushi T, Ouvrier RA, Parker GD, Graham RI, da Silva M, Halmagyi GM. Vestibular abnormalities in CHARGE association. Ann Otol Rhinol Laryngol, 1997; 106(2): 129-34.

7. Abe S, Usami S, Shinkawa $\mathrm{H}$ et al. Three familial cases of hearing loss associated with enlargement of the vestibular aqueduct. Ann Otol Rhinol Laryngol 1997;106: 1063-9.

8. Aschendorff A, Marangos N, Laszig R. Large vestibular aqueduct syndrome and its implication for cochlear implant surgery. Am J Otol, 1997; 18: S57.

9. Emmett JR. The large vestibular aqueduct syndrome. Am J Otol, 1985; 6: 387-415.

10. Fahy CP, Carney AS, Nikolopoulos TP, Ludman CN, Gibbin KP. Cochlear implantation in children with large vestibular aqueduct syndrome and a review of the syndrome. Int J Pediatr Otorhinolaryngol, 2001; 59(3): 207-15.

11. Jackler RK, De La Cruz A. The large vestibular aqueduct syndrome. Laryngoscope, 1989; 99(12): 1238-42.
12. Govaerts PJ, Casselman J, Daemers K, De Ceulaer G, Somers T, Offeciers FE. Audiological findings in large vestibular aqueduct syndrome. Int J Pediatr Otorhinolaryngol, 1999; 51(3): $157-64$.

13. Ko HC, Liu TC, Lee LA, Chao WC et al. Timing of surgical intervention with cochlear implant in patients with large vestibular aqueduct syndrome. PLoS One, 2013; 8(11): e81568

14. Natarajan K, Raghunandhan S, Senthilvadivu, Sathiya M, Kameswaran M. The pulsatile stapes: an unusual sign in large vestibular aqueduct syndrome. Indian J Otolaryngol Head Neck Surg, 2010; 62(Suppl.1): 16-8.

15. Harker LA, Vanderheiden S, Veazey D, Gentile N, McCleary E. Multichannel cochlear implantation in children with large vestibular aqueduct syndrome. Ann Otol Rhinol Laryngol Suppl, 1999; 177: 39-43.

16. Wootten CT, Backous DD, Haynes DS. Management of cerebrospinal fluid leakage from cochleostomy during cochlear implant surgery. Layngoscope, 2006; 116(11): 2055-9.

17. Loundon N, Leboulanger N, Maillet J, Riggouzzo A et al. Cochlear implant and inner ear malformation. Proposal for an hyperosmolar therapy at surgery. Int J Pediatr Otorhinolaryngol, 2008; 72(4): 541-7.

18. Miyamoto RT, Bichey BG, Wynne MK, Kirk KI. Cochlear implantation with large vestibular aqueduct syndrome. Laryngoscope, 2002; 112: 1178-82.

19. Vassoler TMF, Bergonse GFR, Meira S, Bevilacqua MC, Costa Filho OA. Cochlear implant and large vestibular aqueduct syndrome in children. Braz J Otorhinolaryngol, 2008; 74(2): 260-4.

20. Chen X, Liu B Liu S, Mo L et al. The development of auditory skills in infants with isolated large vestibular aqueduct syndrome after cochlear implantation. Int J Pediatr Otorhinolaryngol, 2011; 75: 943-7. 